Revista Brasileira de Farmacognosia Brazilian Journal of Pharmacognosy 23(1): 58-64, Jan./Feb. 2013

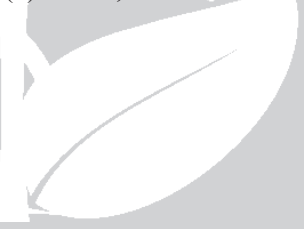

Article

Received 10 Abr 2012

Accepted 8 Aug 2012

Available online 20 Sep 2012

Keywords:

Dimorphandra gardneriana

HPLC

isoquercitrin

quercetin

rutin

validation

ISSN 0102-695X

DOI: 10.1590/S0102-695X2012005000111

\section{Development and validation of a HPLC method for the quantification of three flavonoids in a crude extract of Dimorphandra gardneriana}

\author{
Leonardo P. Landim, " George S. Feitoza, José G. M. da Costa
}

Programa de Pós-graduaçăo em Bioprospecção Molecular, Departamento de Química Biológica, Laboratório de Pesquisa em Produtos Naturais, Universidade Regional do Cariri, Brazil.

\begin{abstract}
A method for separation and quantification of three flavonoids by reverse-phase high performance liquid chromatography (HPLC) was developed and validated. Flavonoids present in a crude methanolic extract of the inner bark of Dimorphandra gardneriana Tul., Fabaceae, were analyzed. Rutin, isoquercitrin and quercetin were used as calibration standards. The analysis was performed using a Thermo Scientific Hypersil C18 column (250 x $4.0 \mathrm{~mm}$ i.d., $5 \mu \mathrm{m}$ particle size), as stationary phase, with a flow rate of $0.8 \mathrm{~mL} / \mathrm{min}$ and detection at a wavelength of $356 \mathrm{~nm}$. The proposed method was validated by resolution RE No. 899/2003 of the National Health Surveillance Agency. In this study, an excellent linearity was obtained with $r$ higher than 0.99 . Besides, the chromatographic peaks showed good resolution. With other validation data, including precision, specificity, accuracy and robustness, this method demonstrated good reliability and sensitivity, and can be conveniently used for the quantification of rutin, isoquercitrin and quercetin in crude methanolic extract of D. gardneriana pods. Furthermore, there are the advantages of easy sample preparation and short time between each injection.
\end{abstract}

\section{Introduction}

Dimorphandra gardneriana Tul., Fabaceae, known as "fava-d'anta" and "faveiro" is a Brazilian native leguminous tree, naturally found in the states of Maranhão, Piauí, Ceará, Pernambuco, Bahia, Pará, Goiás, Mato Grosso and Minas Gerais. The seed pod of "favad'anta" is one of the sources for the extraction of rutin on an industrial scale. Rutin belongs to an important class of flavonoids, vital in their ability to increase the strength of the capillaries and to regulate their permeability (Montano et al., 2007).

Rutin may be used in the treatment and prevention of small varicose veins. This substance is also used in mesotherapy or intradermotherapy to stimulate circulation in treatments against cellulite. It has been used for preparing patients with jaundice for surgery (Silva et al., 2007).

Quercetin is another substance extracted from $D$. gardneriana and of great interest in the pharmaceutical industry. It is a natural polyphenolic antioxidant, present in vegetables, fruits and juices. Chemically, quercetin is an aglycone of rutin and other glycosides. It is a powerful antioxidant and free radical scavenger (Filho et al., 2001).
Another substance that may be found in D. gardneriana is isoquercitrin. It has been shown to play protective roles against lipid peroxidation and oxidative stress (Silva et al., 2008).

However, one of the impediments in the acceptance of herbal products worldwide is the lack of standard quality control profiles (Shinde et al., 2009). Chemical and chromatographic techniques may be used to aid in the identification of an herbal material or extract. Chromatographic techniques such as HPLC, TLC, GC and capillary electrophoresis and spectroscopic methods such as IR, NMR and UV may also be used for fingerprinting (Patra et al., 2010).

In order to control the quality of herbal drugs in a better way, we must develop new techniques and terms to the maximum extent. The development and validation of an efficient analytical method is an integral part of the quality control of the source material, to guarantee the safety and effectiveness of the resulting compound (Hefnawy et al., 2006).

Thus, considering the pharmacological potential of D. gardneriana and the lack of specifications for the quality control of this plant raw material, which is a pre-requisite for the production and registration of 
phytomedicines (Anvisa, 2010), the objective of the present study was to develop and validate a method for the separation and quantitative analysis of rutin (1), quercetin (2) and isoquercitrin (3) by HPLC obtained from a methanolic extract of the inner bark of pods of $D$. gardneriana. This will provide the scientific basis for the quality control of extracts prepared from the inner bark of this plant. The choice of these three flavonoids was based on other studies, which reported the presence of these compounds in other species of Dimorphandra (Sousa et al., 1991; Ferreira et al., 2001; Lucci \& Mazzafera, 2009). The method was validated according to regulation RE 899/2003 of the National Health Surveillance Agency, Brazil (Anvisa, 2003). The following validation characteristics were assessed: specificity, linearity, limit of detection and quantification, accuracy, precision and robustness.

\section{Materials and Methods}

\section{Plant material}

Pods of Dimorphandra gardneriana Tul., Fabaceae, were collected between June and July of 2010 in the city of Crato, State of Ceará, Brazil (Line E, Floresta Nacional do Araripe). The plant material was identified by Prof. Dr. Maria Arlene Pessoa da Silva from the Department of Biological Sciences of Universidade Regional do Cariri. Exsiccates (number 18639) of the species were deposited in the Herbarium Caririense Dárdano de Andrade Lima in the same institution.

\section{Preparation of the extract}

The plant material was submitted to a drying process at room temperature. The bark and seeds were then removed. The inner bark $(1 \mathrm{~kg})$ was separated and triturated. The powder was weighed and extracted with 2 $\mathrm{L}$ methanol, at room temperature, for $72 \mathrm{~h}$. Afterwards, the liquid was filtered and concentrated using a rotary evaporator under reduced pressure to obtain $18 \mathrm{~g}$ of crude extract.

\section{Chemicals and reagents}

All reagents and solvents were analytical and HPLC grades (Tedia, USA), except phosphoric acid (Vetec, Brazil) and sodium dihydrogen phosphate (Caledon, Canada). Ultra-pure water obtained using a Milli-Q Gradient ${ }^{\mathbb{B}}$ apparatus (Millipore, USA) with conductivity of $0.60 \mu \mathrm{S} / \mathrm{cm}$ was used in all experiments. Rutin, quercetin and isoquercitrin (Sigma, USA) of the highest grade (purity $>98.0 \%$ ) were used as the external standards.

\section{Instrumentation and chromatographic conditions}

The analyses were carried out using an HPLC system (Shimadzu, USA) consisting of a solvent delivery pump (Model LC-10 ADvp), a variable wavelength UV/ VIS detector (Model SPD 10 AVP), a manual injection valve (Rheodyne ${ }^{\circledR}$, USA) with a $20 \mu \mathrm{L}$ loop, and degasser (DGU 14A). Data collection and analyses were performed using CLASS-VP ${ }^{\mathrm{TM}}$ System Software. A gradient elution was performed on a Thermo Scientific Hypersil $\mathrm{C}_{18}$ column ( $250 \times 4.0 \mathrm{~mm}$ i.d., $5 \mu \mathrm{m}$ particle size) (Thermo Scientific, USA). The mobile phase consisted of two different solutions, solution A and solution B. Both solutions consisted of tetrahydrofuran (THF) and sodium dihydrogen phosphate buffer $(15.6 \mathrm{~g} / \mathrm{L})$ adjusted to $\mathrm{pH}$ 3.0 with phosphoric acid, where the proportion of THF and buffer was 5:95 for solution A and 40:60 for solution B. All solutions were degassed and filtered through a 0.45 $\mu \mathrm{m}$ pore size filter (Millipore, USA). Separations were effected by a gradient elution program as follows: from 0 to $10 \mathrm{~min}$, solution B followed a linear change from $50 \%$ to $100 \%$; from 10 to $15 \mathrm{~min}$, B was isocratic at $100 \%$; from 15 to $16 \mathrm{~min}$, B linearly changed from $100 \%$ to $50 \%$ and from 16 to $20 \mathrm{~min}, \mathrm{~B}$ was isocratic at $50 \%$. The mobile phase flow rate was $1 \mathrm{~mL} / \mathrm{min}$ and the injection volume was $20 \mu \mathrm{L}$. UV detection was performed at 356 $\mathrm{nm}$.

Using these chromatographic conditions, it was possible to confirm the retention time of rutin,<smiles>[R]c1c(-c2ccc(O)c(O)c2)oc2cc(O)cc(O)c2c1=O</smiles>

$1 \mathrm{R}=\mathrm{a}$

$2 \mathrm{R}=\mathrm{H}$

$3 \mathrm{R}=\mathrm{b}$

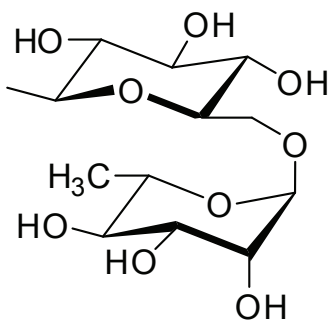

a

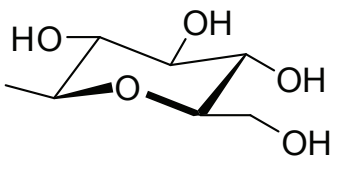

b 
quercetin and isoquercitrin by injection of each standard separately.

\section{Sample preparation}

In the present study, $100 \mathrm{mg}$ of crude extract were dissolved in $100 \mathrm{~mL}$ methanol. This sample was submitted to sonication to speed dissolution of the particles. Next, $2 \mathrm{~mL}$ were transferred to a suitable volumetric flask and diluted to $100 \mathrm{~mL}$ with mobile phase (solution B). A solution was obtained with a known concentration of $0.02 \mathrm{mg} / \mathrm{mL}$.

\section{Preparation of standard solution}

Accurately weighed appropriate amounts of the reference compounds (rutin RUT; quercetin QUE; isoquercitrin ISO) were mixed and dissolved in methanol in a $200-\mathrm{mL}$ volumetric flask, to obtain a stock solution. The concentration of the three compounds in this solution was $1000 \mu \mathrm{g} / \mathrm{mL}$ (RUT), $166.7 \mu \mathrm{g} / \mathrm{mL}$ (ISO) and $13.3 \mu \mathrm{g} / \mathrm{mL}$ (QUE). Besides, external standards were established at five data points covering the concentration range of each compound according to the level estimated in the plant sample. Working solutions were prepared by stepwise dilution of the stock solution with solution B of mobile phase.

\section{Method validation}

In the validation of the analytical method used for the quantification of rutin, quercetin and isoquercitrin in the methanolic extract of $D$. gardneriana, the following parameters were determined: specificity, linearity, sensitivity, accuracy, precision and robustness.

\section{Specificity}

Specificity is the ability of a method to discriminate between the study analyte(s) and other components in the sample. Specificity of the HPLC method is demonstrated by the separation of the analytes from other potential components such as impurities, degradants, or excipients (Dong, 2006). In this study, the specificity was demonstrated by running a procedural blank, where $2 \mathrm{~mL}$ of methanol were transferred to a suitable volumetric flask and diluted to $100 \mathrm{~mL}$ with mobile phase (solution B). In addition, the resolution between the peaks of the main flavonoids that could be found in methanolic extracts of D. gardneriana was determined by analysis of chromatograms of the standard solution and the sample solution. This resolution was calculated by Shimadzu CLASS-VP ${ }^{\circledR}$ software version $6.12 \mathrm{SP} 2$.

\section{Linearity}

The linearity between peak area and concentration was analyzed using three calibration curves obtained with standard solutions at five different concentrations of each standard RUT, QUE and ISO. The concentrations of the three compounds in the solution that was considered $100 \%$ was $15 \mu \mathrm{g} / \mathrm{mL}$ (RUT), $2.5 \mu \mathrm{g} / \mathrm{mL}$ (ISO) and $0.2 \mu \mathrm{g} / \mathrm{mL}$ (QUE). The other concentration levels used to construct calibration curves were $80,90,110$ and $120 \%$ of the concentration mentioned above (Anvisa, 2003). The data for peak area versus drug concentration were treated by linear regression analysis.

\section{Sensitivity}

The limit of detection ( $L O D)$ and the limit of quantification $(L O Q)$ were determined from the calibration curves of the RUT, QUE and ISO standards. $L O D$ was calculated according to the expression DPx3/ IC, where DP is the standard deviation of the response and IC is the slope of the calibration curve. LOQ was established by using the expression DP x10/IC (Anvisa, 2003).

\section{Accuracy}

The accuracy was evaluated by means of recovery assays carried out by adding known amounts of the RUT and ISO standard to the sample, at three different levels $(5 \%, 10 \%$ and $15 \%)$ of the initial concentration of the sample. For evaluation of recovery of quercetin standard was added to the sample whose final concentration were $0.180,0.200$ e $0.220 \mu \mathrm{g} / \mathrm{mL}$ of this compound. Each solution was injected in triplicate. Average recoveries were calibrated by the formula recovery $(\%)=\{$ (amount found - original amount)/amount spiked \} x 100.

\section{Precision}

The precision of the method was investigated with respect to repeatability, intermediate precision (inter-day variation) and reproducibility by determination of standard solution at $100 \%$ of the test concentration. To assess the intra-day precision (repeatability) of the method, the sample was injected six times within a day. The inter-day precision was determined with the sample assayed on different days and by another analyst. Reproducibility was determined by injection of the sample six times and consequently comparing the results in two different laboratories. The main laboratory was the Quality Control, Farmace Indústria Químico-Farmacêutica Cearense, where all the tests were performed for this validation, while the other was the Central Analítica, Universidade Federal do Ceará, Campus Cariri. Precision was expressed as the relative 
standard deviations (\% RSD) of the concentrations of each compound, RUT, QUE and ISO.

\section{Robustness}

Three sample solutions were prepared and analyzed under the conditions established and by changing the wavelength parameter from $356 \mathrm{~nm}$ to 358 $\mathrm{nm}$, by using columns from different suppliers and by changing the $\mathrm{pH}$ of the mobile phase from 3.0 to 3.1 (Anvisa, 2003).

\section{Statistical analysis}

The data were submitted to statistical analysis using GraphPadPrism $5^{\circledR}$ and Excel ${ }^{\circledR}$ software.

\section{Results and Discussion}

The HPLC method carried out in this study was aimed at developing a chromatographic system, capable of eluting and resolving flavonoid compounds in a crude methanolic extract of Dimorphandra gardneriana Tul., Fabaceae. In the development of the HPLC method for determination of rutin (1), quercetin (2) and isoquercitrin (3) in a methanolic extract of D. gardneriana, several solvent systems (methanol-water, acetonitrile-water, tetrahydrofuran-buffer) and separation columns Thermo Scientific Hypurity $\mathrm{C}_{8}$ column $(250$ x $4.6 \mathrm{~mm}$ i.d., $5 \mu \mathrm{m}$ particle size), Thermo Scientific Hypersil $\mathrm{C}_{18}$ column $(250 \times 4.0 \mathrm{~mm}$ i.d., $5 \mu \mathrm{m}$ particle size, Phenomenex Hyperclone BDS $\mathrm{C}_{18}(100 \times \mathrm{x} 4.6 \mathrm{~mm}$ i.d., $5 \mu \mathrm{m}$ particle size $)$, Restek Pinnacle II $\mathrm{C}_{8}(250 \times 4.6 \mathrm{~mm}$ i.d., $5 \mu \mathrm{m}$ particle size) were evaluated and compared. The Thermo Scientific Hypersil $\mathrm{C}_{18}$ column provided better separation of the plant extract than with other specifications or brands of columns.

The choice of detection wavelength was determined by performing a screening with $10 \mathrm{ppm}$ of rutin, major compound, in methanol in a spectrophotometer UV/ VIS. The UV spectra were recorded from 220 to $360 \mathrm{~nm}$ and exhibited maximum wavelengths at $254 \mathrm{~nm}$ and 356 $\mathrm{nm}$. It was carried out an analysis on HPLC with the two wavelengths and which provided better response even for the others compounds (quercetin and isoquercitrin) was at a wavelength of $356 \mathrm{~nm}$.

The optimization of the chromatographic conditions led to a good resolution of adjacent peaks of the flavonoids in this study when compared to other methods previously described for the quantification of these compounds in crude plant materials (Chou et al., 2009; Batista et al., 2010).

The results for quantification of the flavonoids in the sample were $14.506 \mu \mathrm{g} / \mathrm{mL}$ of rutin and $2.220 \mu \mathrm{g} / \mathrm{mL}$ of isoquercitrin, which means, 72.53 and $11.10 \%$ of each compound contained in the crude extract $(20 \mu \mathrm{g} / \mathrm{mL})$, respectively. Quercetin was not found in concentrations levels possible to be measured. It is important to note that this is the first report of quantification of flavonoids in crude extracts of $D$. gardneriana.

The specificity of the method was evaluated by analysis of the blank, standard and sample solution chromatograms (Figure 1). Good separation between the peaks of RUT, QUE and ISO was achieved, with the retention times, $7.5 \mathrm{~min}$ for rutin, $9 \mathrm{~min}$ for isoquercitrin and $16.5 \mathrm{~min}$ for quercetin. Furthermore, the chromatographic peaks showed good resolution (around 5.7 between RUT and ISO and approximately 27 between RUT and QUE). In relation to assimetry, the peaks showed values between 1.19 and 1.29 for RUT and ISO and 1.48 for asymetry of the peak of QUE.
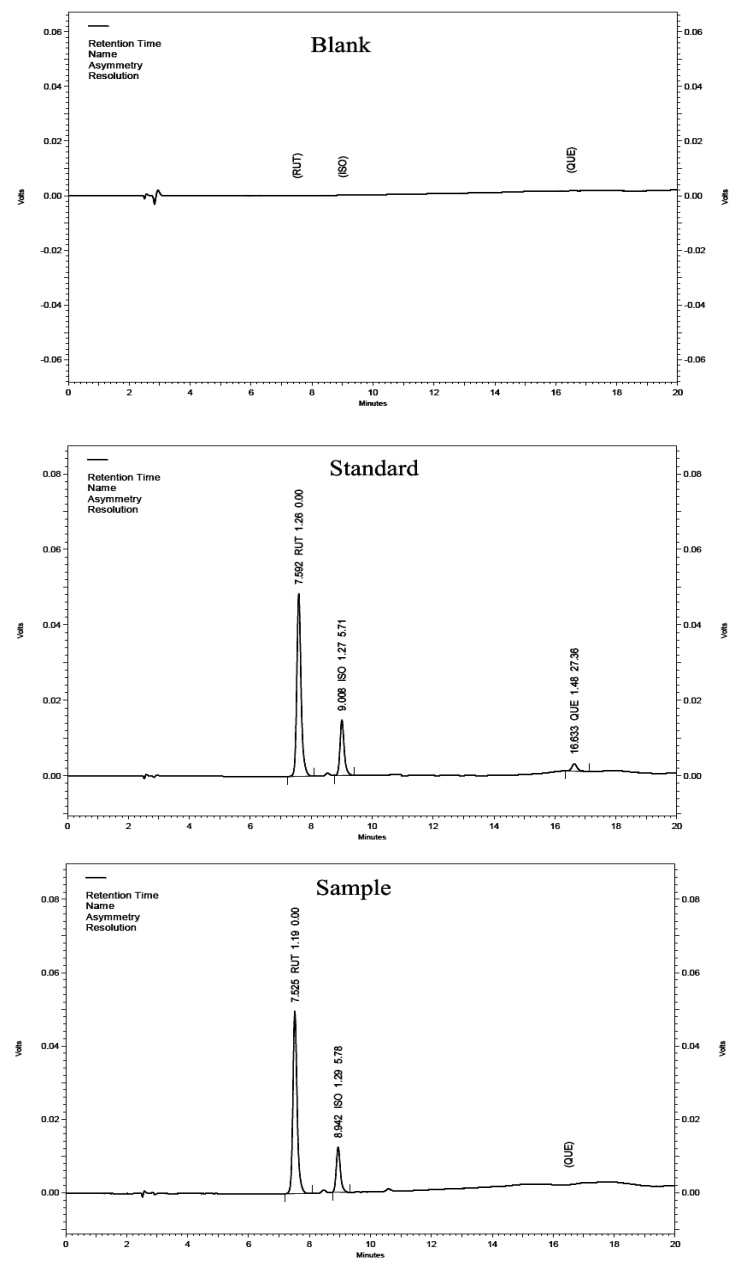

Figure 1. Chromatograms of the blank, standard and sample solution performed on a Thermo Scientific Hypersil $\mathrm{C}_{18}$ column ( $250 \times 4.0 \mathrm{~mm}$ i.d., $5 \mu \mathrm{m}$ particle size) at $356 \mathrm{~nm}$.

Linearity was evaluated by the correlation coefficient $r$, and all values for the three compounds were greater than 0.995 , showing that responses for the standard in the concentration ranges examined (from 
80 to $120 \%$ ) were linear. Besides, according to Anvisa (2003), the minimum acceptable correlation coefficient is 0.990 .

As shown in Table 1, the LOD values were 0.09 $\mu \mathrm{g} / \mathrm{mL}, 0.02 \mu \mathrm{g} / \mathrm{mL}$ and $0.02 \mu \mathrm{g} / \mathrm{mL}$ for the compounds RUT, ISO and QUE, respectively, while the LOQ values were $0.29 \mu \mathrm{g} / \mathrm{mL}, 0.07 \mu \mathrm{g} / \mathrm{mL}$ and $0.05 \mu \mathrm{g} / \mathrm{mL}$.

The recovery of the compounds RUT, QUE and ISO was determined by spiking the crude extract with known amounts of RUT, QUE and ISO standards.
Recovery of each substance was obtained from the calculated amount found and original amount. The results are presented in Table 2 and conform with the recommendations of Anvisa (Anvisa, 2003).

The data of the precision are shown in Table 3. The results display a coefficient of variation less than that recommended by RE 899 (Anvisa, 2003) whose limit is $5 \%$. Also, there were no significant differences between assay results, indicating that the precision of the proposed method was satisfactory.

Table 1. Calibration curve parameters, limit of detection (LOD), limit of quantification (LOQ) for rutin, isoquecitrin and quercetin.

\begin{tabular}{lccccc}
\hline \multicolumn{1}{c}{ Compound } & Calibration curve equation & Correlation coefficient $(\mathrm{r})$ & Linear range $(\mu \mathrm{g} / \mathrm{mL})$ & $\mathrm{LOD}(\mu \mathrm{g} / \mathrm{mL})$ & $\mathrm{LOQ}(\mu \mathrm{g} / \mathrm{mL})$ \\
\hline rutin & $\mathrm{y}=32844.31 \mathrm{x}+178861.53$ & 0.9987 & $12-18$ & 0.09 & 0.29 \\
isoquercitrin & $\mathrm{y}=58813.51 \mathrm{x}+52111.13$ & 0.9983 & $2-3$ & 0.02 & 0.07 \\
quercetin & $\mathrm{y}=128566.83 \mathrm{x}+25130.40$ & 0.9982 & $0.16-0.24$ & 0.02 & 0.05 \\
\hline
\end{tabular}

Table 2. Results of accuracy determination by analyzing of the rutin, quercetin and isoquercitrin of known concentrations.

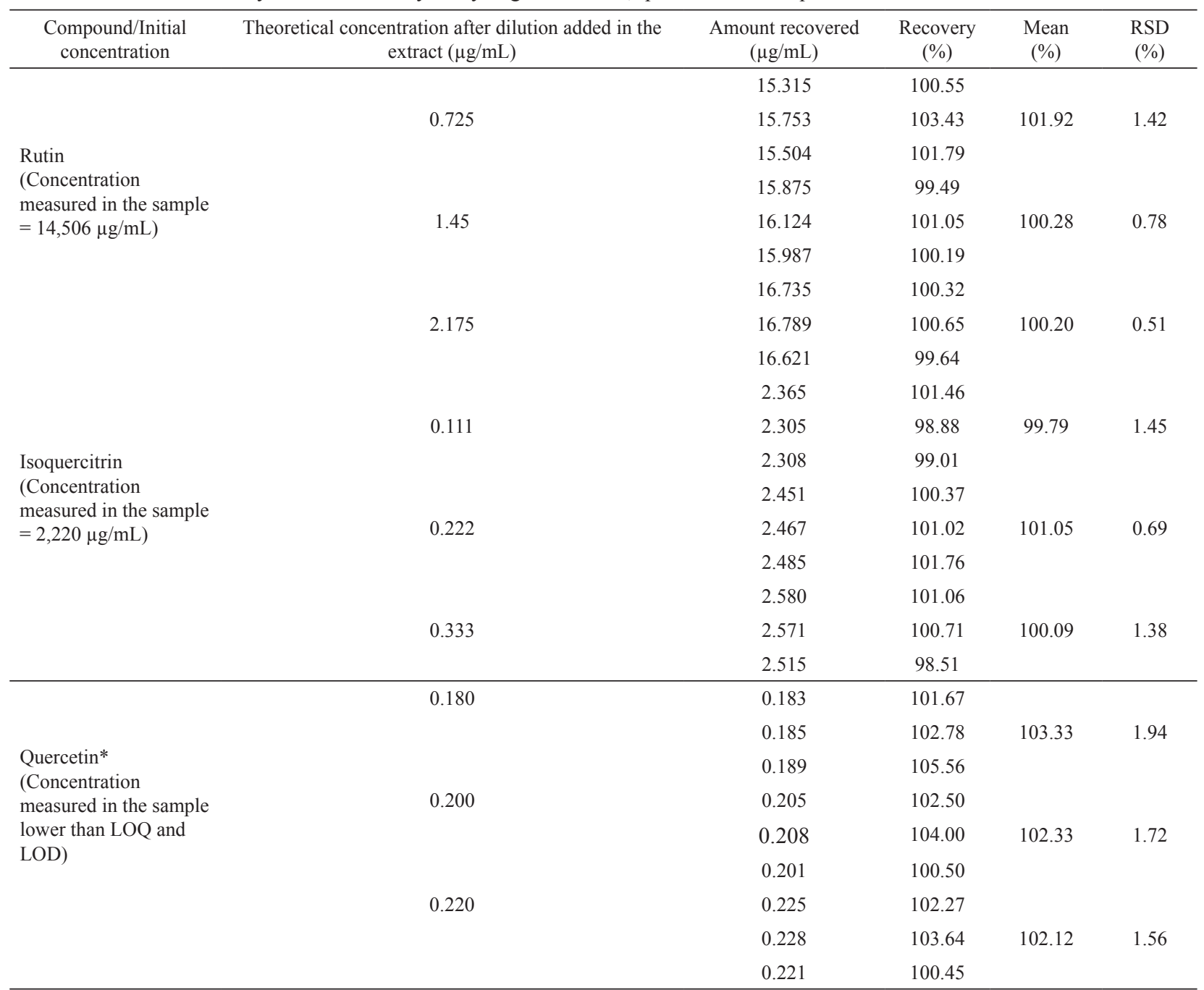

*Since the concentration of quercetin measured was lower than LOQ and LOD to calculate the recovery its initial concentration was considered as $0.00 \mu \mathrm{g} / \mathrm{mL})$. 
Table 3. Results of the repeatability, intermediate precision and reproducibility tests.

\begin{tabular}{|c|c|c|c|}
\hline \multirow{2}{*}{\multicolumn{2}{|c|}{ Compound }} & Repeatability & \multirow{2}{*}{$\operatorname{RSD}(\%)$} \\
\hline & & Mean $(\mu \mathrm{g} / \mathrm{mL}) \pm$ standard deviation $(\mathrm{n}=6)$ & \\
\hline rutin & & $15.062 \pm 0.083$ & 0.551 \\
\hline isoquercitrin & & $2.491 \pm 0.007$ & 0.294 \\
\hline quercetin & & $0.201 \pm 0.003$ & 1.457 \\
\hline \multirow{2}{*}{\multicolumn{2}{|c|}{ Compound }} & Intermediate precision & \multirow{2}{*}{$\operatorname{RSD}(\%)$} \\
\hline & & Mean $(\mu \mathrm{g} / \mathrm{mL}) \pm$ standard deviation $(\mathrm{n}=12)$ & \\
\hline rutin & & $15.076 \pm 0.103$ & 0.692 \\
\hline isoquercitrin & & $2.494 \pm 0.013$ & 0.473 \\
\hline quercetin & & $0.200 \pm 0.002$ & 1.170 \\
\hline \multirow{2}{*}{ Compound } & \multirow{2}{*}{ Laboratory } & Reproducibility & \multirow{2}{*}{$\operatorname{RSD}(\%)$} \\
\hline & & Mean $(\mu \mathrm{g} / \mathrm{mL}) \pm$ standard deviation $(\mathrm{n}=6)$ & \\
\hline \multirow[t]{2}{*}{ rutin } & Farmace & $15.065 \pm 0.101$ & 0.668 \\
\hline & UFC & $15.213 \pm 0.121$ & 0.621 \\
\hline \multirow[t]{2}{*}{ isoquercitrin } & Farmace & $2.494 \pm 0.020$ & 0.798 \\
\hline & UFC & $2.594 \pm 0.044$ & 1.699 \\
\hline \multirow[t]{2}{*}{ quercetin } & Farmace & $0.201 \pm 0.003$ & 1.587 \\
\hline & & $0.202 \pm 0.002$ & 1.047 \\
\hline
\end{tabular}

Robustness was evaluated to ensure that the HPLC method is insensitive to small changes in the experimental conditions. In this study, the wavelength, column supplier and $\mathrm{pH}$ of the mobile phase were changed. None of the modifications caused any significant change in the resolution or response of the RUT, QUE and ISO peaks.

All results were displayed according to the Guide for Validation of Analytical and Bioanalytical Methods RE 899 (Anvisa, 2003).

The quantitative method developed here was successfully applied in the simultaneous analysis of three different compounds in a crude methanolic extract of $D$. gardneriana. Taking into account the results obtained in this study, the proposed method can be conveniently used for the analysis of rutin, isoquercitrin and quercetin in crude methanolic extracts of $D$. gardneriana pods.

The proposed method demonstrated high specificity at $356 \mathrm{~nm}$ detection for the pod extract of $D$. gardneriana showing reliability in the quantification of RUT, ISO and QUE. Furthermore, the method has the following advantages: rapid extraction, easy sample preparation and short time between injections. In summary, the method above can be considered specific, exact, precise, linear, robust and easy to perform.

\section{Acknowledgment}

The authors would like to acknowledge financial support from Brazilian research agencies CAPES, CNPq, CNPQ-INCT for Excitotoxicity and Neuroprotection.

\section{References}

Anvisa 2003. Resolução-RE no 899: Guia para validação de métodos analíticos e bioanalíticos. Diário Oficial da União. http://www.in.gov.br/imprensa/visualiza/index. jsp?jornal $=1$ \&pagina $=56 \&$ data $=02 / 06 / 2003$, accessed in Jul 2011.

Anvisa 2010. Resolução-RDC no 14: Dispõe sobre o registro de medicamentos fitoterápicos. Diário Oficial da União. http://www.in.gov.br/visualiza/index.jsp?data $=05 / 0$ 4/2010\&jornal $=1 \&$ pagina $=\quad 85 \&$ totalArquivos $=160$, accessed in Nov 2011.

Batista ANL, Colombo R, Pascoli IC, Teles HL, Silva GH, Bonfim GCC, Burgos RCR, Cavalheiro AJ, Bolzani VS, Silva DHS, Reimberg MCH 2011. Development and validation of a HPLC method for standardization of herbal and commercial extracts of Myrcia uniflora. Rev Bras Farmacogn 21: 402-406.

Chou G, Xu SJ, Liu D, Koh GY, Zhang J, Liu Z 2009. Quantitative and fingerprint analyses of chinese sweet tea plant (Rubus suavissimus S. Lee). J Agric Food Chem 57: 1076-1083.

Dong MW 2006. Regulatory aspects of HPLC analysis: HPLC system and method validation. In Dong MW (org.) Modern HPLC for practicing scientists. John Wiley \& Sons, p. 230.

Ferreira RA, Botelho AS, Davide AC, Malavasi MM 2001. Morfologia de frutos, sementes, plântulas e plantas jovens de Dimorphandra mollis Benth. - faveira (Leguminoseae- Caesalpinioideae). Rev Bras Bot 24: 303-309.

Filho WD, Silva EL, Boveris, A2001. Flavonóides, antioxidantes 
de plantas medicinais e alimentos: importância e perspectivas terapêuticas. In: Yunes RA, Calixto JB Plantas Medicinais sob a ótica da química medicinal moderna. São Paulo: Universitária, p.317-334.

Hefnawy MM, Sultan MA, Al-Shehri MM 2006. Direct enantiomeric resolution of betaxolol with application to analysis of pharmaceutical products. Anal Chem Insights 1: 13-20.

Lucci N, Mazzafera P 2009. Rutin synthase in fava d'anta: Purification and influence of stressors. Can J Plant Sci 89: 895-902.

Montano HG, Silva GS, Rocha RC, Jimenez, NZA, Pereira RC, Brioso PST 2007. Phytoplasma in "fava d'anta" tree (Dimorphandra gardneriana) in Brazil. Bull Insectology 60: 147-148.

Patra KC, Pareta SK, Harwansh RK, Kumar KJ 2010. Traditional approaches towards standardization of herbal medicines-A review. J Pharm Sci Technol 2: 372-379.

Shinde VM, Dhalwal K, Potdar M, Mahadik KR 2009. Application of quality control principles to herbal drugs. Int J Phytomed 1: 4-8.

Silva SR 2007. Ecologia de População e Aspectos Etnobotânicos de Dimorphandra gardneriana Tullasne (LeguminosaeMimosaceae) na Chapada do Araripe, Ceará-CE. Brasília, 105p. Tese de Doutorado. Programa de Pósgraduação em Ecologia, Universidade de Brasilía.

Silva BA, Malva O, Dias AC 2008. St. John's Wort (Hypericum perforatum) extracts and isolated phenolic compounds are effective antioxidants in several in vitro models of oxidative stress. Food Chem 110: 611-619.

Sousa MP, Matos MEO, Matos FJA, Machado MIL, Cravetro AA 1991. Constituintes químicos ativos de plantas medicinais brasileiras. Fortaleza: Universidade Federal do Ceará.

\section{*Correspondence}

Leonardo Pinheiro Landim

Departamento de Química Biológica, Laboratório de Pesquisa em Produtos Naturais, Universidade Regional do Cariri

Av. Cel Antonio Luiz, 1161, 63.000-000 Crato-CE, Brazil galberto.martins@urca.br

Tel.: +55883102 1212

Fax: +558831021212 